\title{
PRESENTACION DE DOS TEXTOS DE NORBERT ELIAS
}

\section{Ramón Ramos y Helena Béjar}

Universidad Complutense de Madrid

Norbert Elias fue un escritor prolífico. Hasta los últimos años de su dilatada vida, cuando sus problemas con la vista le impedían ya escribir y se veía obligado a dictar sus trabajos, no cejó en su labor de publicista. Sus intereses fueron muy variados y por ello también lo fueron los temas a que dedicó sus escritos. Pero hay todo menos dispersión en su obra. Como se ha destacado en los distintos trabajos publicados en este número monográfico, hay un hilo sólido y explícito que vertebra su obra y le confiere una rotunda unidad. Lo proporciona la idea de un proceso multisecular hacia una creciente civilización. En esta clave han de ser leídos e interpretados el resto de los fenómenos socioculturales, ya se trate de manifestaciones artísticas o culturales, fenómenos políticos, militares o económicos, o incluso de biografías específicas. La civilización, su génesis y complejo desarrollo, es así, directa o indirectamente, la gran corriente amazónica en la que acaban desembocando sus numerosos libros, artículos y conferencias.

La publicación de estos dos artículos de la última época de la vida de Elias (1981 y 1987) permite comprobar lo dicho. En ambos, a pesar de sus diferencias temáticas, la argumentación de Elias se dirige a situar el objeto de estudio dentro de la corriente civilizadora. En un caso, porque sólo podemos comprender el fenómeno social de la violencia si tomamos en consideración cómo se operó el «milagro» civilizador que permitió pacificar las relaciones sociales y si atendemos a la precariedad de los resultados de ese proceso y a su desarrollo 
aún incompleto y desigual. En el otro caso, porque el arte barroco y el posterior clasicismo sólo se pueden entender en el marco de ese subepisodio de la civilización multisecular que es la sociedad cortesana. Sólo ésta y sus específicas características figuracionales -es decir, su peculiar equilibrio de poder, su aristocracia transnacional y cosmopolita, su burguesía desplazada o integrada en los círculos de prestigio de la corte, etc.- pueden hacernos comprender esa especial sensibilidad por la bella palabra, el juego galante, la corrección formal y el ingenio chispeante que singularizan a la literatura barroca. Y sólo las diferencias nacionales entre las distintas sociedades cortesanas nos permiten también comprender su destino posterior, en unos casos (Francia) como modelo clásico para los siglos posteriores, en otros (Alemania) como literatura artificiosa y desestimada que sería desplazada por la fría espiritualidad de una literatura específicamente burguesa.

Pero no se puede limitar a esto la relevancia de esos dos textos. Su lectura permite dar con otras facetas muy recurrentes en Elias, definitorias de su estilo literario y argumental, de su idea sobre el cometido de la sociología y la relevancia de la historia, de la imbricación de su experiencia histórica particular y su obra académica.

En efecto, en ambos escritos se pone de relieve lo que J. M. González García ha analizado de forma tan completa en su artículo: la presencia y el protagonismo de la literatura en la sociología de Elias. No se trata, evidentemente, del hecho de que en uno de los artículos se aborde temáticamente un determinado estilo literario, sino, más allá de eso, del papel revelatorio que Elias asignaba en general a la literatura. Se puede comprobar en su artículo sobre la violencia. En él, el síndrome de la violencia se pone especialmente de manifiesto gracias a la utilización de fuentes literarias. Los literatos son espejos de un tiempo y no sólo los grandes autores que culminan nuestros panteones culturales, sino también los escritores modestos que Elias eleva al estatuto de fiables testigos de época.

El amor por la literatura desborda, por lo demás, la significación sociológica que se le acuerda. El trabajo sobre la literatura barroca es buena muestra de ello. En él, Elias se convierte en crítico literario y se lamenta de que el desdén burgués por la «artificiosa» literatura de corte tuviera el efecto de que el clasicismo alemán no preservara el legado de la bella forma cortesana, su dominio de la imagen y el ritmo, y optara por un seco espiritualismo o un populismo poco natural. En comentarios tales se hace presente un escritor que era algo más que un lector literario informado o un crítico ocasional. Conviene así recordar que Elias, admirador confeso de Brecht, publicó un libro de poesía, Los der Menschen: Gedichte/Nachdichtungen.

Otro aspecto de su obra que se revela en estos escritos es su concepción del papel de la sociología. Como ha destacado Helena Béjar, el modelo eliasiano de sociólogo es el zapador de mitos, un analista que se distancia del halo emocional de los acontecimientos que nos inquietan y que, por ello, logra ver con frialdad. Tal es la imagen que defiende en su artículo sobre la violencia terro- 
rista en Alemania. Pero, además, la sociología es pragmáticamente relevante, pues gracias a la frialdad con que mira el mundo puede apuntarnos, como se dice expresivamente en ese trabajo, «si, quizás, se puede hacer algo».

Como reserva de experiencia colectiva, el sociólogo ha de contar además con la historia, comparando lo que ocurre ahora con lo que ocurrió en otros momentos y situando la actualidad en el proceso histórico del que ha surgido. La historia, como magistra vitae, se hace socialmente insustituible y sociológicamente central. Y, así, Elias muestra cómo la violencia del ethos guerrero de la aristocracia y parte de la burguesía guillermina y la violencia colectiva y desesperada de la época de Weimar son experiencias históricas claves, por sus diferencias y similitudes, para una comprensión ajustada de la violencia terrorista posterior al gran «sueño» de 1968. Hay algo común en todas esas situaciones: la pérdida de sentido después de la frustración de un sueño colectivo. Sobre esas semejanzas se acumulan las diferencias, particularizando cada coyuntura histórica. Pero, en cualquier caso, es la comparación histórica la que permite comprender incluso la más rabiosa actualidad.

Hay un último rasgo que colorea los dos artículos y es muy característico de la obra de Elias. Se trata del peso o presencia de lo biográfico y personal en su sociología. Es muy visible en el artículo sobre la violencia. Allí los análisis se entretejen con recuerdos personales: lo que vivió, los amigos muertos. Pero incluso su incursión en la literatura barroca muestra señas personales en esa evocación de su ciudad natal, Breslau, que, como la púdica Florencia de Dante siglos antes, se protegía de la barbarie reinante tras los fuertes muros de la muralla antigua; Breslau y su poeta Hofmannswaldau. Hay una suerte de homenaje a la ciudad en la que Elias confesó haber vivido una infancia feliz a la que siguió una vida de múltiples exilios.

No es un rasgo anecdótico. La implicación biográfica de la sociología del teórico del distanciamiento es una muestra más de la tensión interna de quien en los momentos más trágicos de su vida no cejó en el empeño de mantener una cada vez más problemática esperanza en un estado de civilización que había conocido en su infancia y al que dedicó toda una vida de estudio. Se hace así presente el autor de una obra entreverada de optimismo histórico, El proceso de la civilización, dedicada a la memoria de su madre, "Sophie Elias, muerta en Auschwitz 1941 (?)». 